\title{
Intergenerational Mobility and the Effects of Parental Education, Time Investment, and Income on Children's Educational Attainment
}

\author{
George-Levi Gayle, Limor Golan, and Mehmet A. Soytas
}

\begin{abstract}
This article analyzes the mechanisms through which parents' and children's education are linked. It estimates the causal effect of parental education, parental time with children, and parental income during early childhood on the educational outcomes of children. Estimating the causal effects of time with children, income, and parental education is challenging because parental time with children is usually unavailable in many datasets and because of the problem of endogeneity of parental income, time with children, and education. The authors, therefore, use an instrumental variables approach to estimate the causal effects. They find that once they account for the parental time input with children, parental income during the first five years is no longer statistically significant. The parental time investments of both parents in early childhood are each statistically and quantitatively significant determinants of the educational outcomes of children. (JEL C13, J13, J22, J62)
\end{abstract}

Federal Reserve Bank of St. Louis Review, Third Quarter 2018, 100(3), pp. 281-95. https://doi.org/10.20955/r.100.281-95

\section{INTRODUCTION}

Income inequality has increased substantially in the United States since the 1970s. One concern about higher income inequality is that it is linked to intergenerational mobility. Intergenerational mobility refers to the change in socioeconomic outcomes from one generation to the next-from parents to their children as adults-and usually is measured by the intergenerational correlation in income, education, or social class. A strong link between the incomes and educations of parents and children across generations is a sign of low intergenerational income mobility and likely means that children born to less-advantaged households will be less advantaged as adults. Economies with higher inequality tend to have lower intergenerational mobility (a phenomenon known as the "Great Gatsby" curve). Since education is an important determinant of earnings and many other life outcomes, we focus on inter-

George-Levi Gayle and Limor Golan are associate professors at Washington University in St. Louis and research fellows at the Federal Reserve Bank of St. Louis. Mehmet A. Soytas is an assistant professor at Ozyegin University.

(C) 2018, Federal Reserve Bank of St. Louis. The views expressed in this article are those of the author(s) and do not necessarily reflect the views of the Federal Reserve System, the Board of Governors, or the regional Federal Reserve Banks. Articles may be reprinted, reproduced, published, distributed, displayed, and transmitted in their entirety if copyright notice, author name(s), and full citation are included. Abstracts, synopses, and other derivative works may be made only with prior written permission of the Federal Reserve Bank of St. Louis. 


\section{Gayle, Golan, Soytas}

generational transmission of education, specifically, the mechanisms that link children's education to their parents' education. It is well documented that highly educated parents are more likely to have highly educated children. Since many skills are formed before individuals enter college, we seek to understand early determinants that affect economic mobility across generations. In particular, we focus on the impact of parental monetary investment and the time parents spend with their children when their children are young on the children's completed education.

There are many possible underlying mechanisms for the intergenerational correlation in education, and it is difficult to determine causal effects of the different determinants (see Black and Devereux, 2011, for a survey of the literature). First, more-educated parents often have higher incomes, which may affect the educational attainment of their children. However, more-educated parents may have more skills and abilities that are directly transmitted to their children. Therefore, the intergenerational correlation in education observed in the data may reflect the fact that more-able parents get more education and have more-able children who get more education. This is known as the "ability bias." Lastly, more-educated parents tend to spend more time with their children. By time, we mean parental time allocated to the care of their children, which is an essential input in the development of the children's skills, or human capital. Parental time with children, then, captures the investment in human-capitalenhancing activities for the children. However, it is possible that parents with higher ability tend to spend more time with their children, which introduces an endogeneity problem. This problem arises since it is hard to distinguish whether parental time investment itself enhances the human-capital development of children or whether it simply reflects the fact that moreeducated parents tend to spend more time with their children and that their parental skills and education affect the development of the children's skills.

Moreover, both income and parental time with children depend on how households choose to allocate their time. That is, college-educated mothers married to college-educated men may spend different amounts of time with their children and in the labor market than collegeeducated mothers married to men with only a high school education. Since there is typically assortative mating - that is, people tend to marry people with similar education-it is important to account directly for the characteristics and inputs of both parents. These issues, in addition to the fact that there is a lack of data on parental time investment, pose difficulties for estimation of the causal effect of each of the above factors on children's educational outcomes.

In this article, we estimate the causal effects of parental education and income and time spent with children in the first five years of life on a child's educational outcome. It is based on Gayle, Golan, and Soytas (2015). There is an extensive literature on estimation of the production function of skills (see Heckman and Mosso, 2014, for a comprehensive survey); however, this literature does not identify the causal impact of parental time on completed education (typically due to lack of data on parental time investment). An exception is Del Boca, Flinn, and Wiswall (2014), who estimate a detailed process of skill formation of young children using data on parental time with children to identify the causal effect of parental time. However, they measure the effect on test scores and not on completed education. We first show that fathers' income in the first five years of their children's lives has a positive effect on the edu- 
cational outcomes of their children. This outcome still holds once we account for endogeneity by using instrumental variables techniques. However, once we include parental time measures, the income variables are no longer statistically significant. Measures of parental time are not typically accounted for in the literature since data on them are not typically available. We find, however, that parental education is still important. Parental time of both mothers and fathers each has a significant impact on children's educational attainment. Our results, therefore, do not support the idea that household credit constraints, at least when children are young, have a direct effect on children's educational outcomes. However, credit constraints could have an indirect effect if they reduce the amount of time parents spend with their children.

This article is organized as follows: Section 2 describes the data and documents the relationship between parental education and income and children's educational outcomes. Section 3 estimates the causal effect of parental time and income on children's educational outcomes. Section 4 provides discussion and concludes.

\section{EDUCATIONAL OUTCOMES, PARENTAL EDUCATION, AND INCOME}

We begin by documenting the correlation between children's educational outcomes and the socioeconomic status of their parents, using Panel Study of Income Dynamics (PSID) data of two generations of parents and children. The PSID is the longest-running longitudinal household survey in the world. The survey started in 1968 with a nationally representative sample of 5,000 U.S. families and includes continuously collected information on employment, income, wealth, expenditures, health, marriage, childbearing, child development, education, and various other aspects of the family members and their descendants. The PSID is directed by the University of Michigan, and the data are freely available to researchers.

We select individuals from 1968 to 1997 by setting the individual level variables "Relationship to Head" to head, or wife, or son, or daughter. Our main sample contains 423,631 individual-year observations. Only white and black individuals between 17 and 55 years of age are kept in our sample. In the data, we observe the number of children, annual labor income, labor market hours, housework hours, and parental time with children. Table 1 presents the summary statistics of the main variables used in the estimation.

The PSID measures annual hours of housework for each individual; however, it does not provide data on the time parents spend on childcare. 1 The variable for time spent with children is estimated using a version of the approach used in the literature. Hours with children are computed as the deviation of housework hours in a particular year from the average housework hours of individuals with no children, by gender, education, and year (Hill and Stafford, 1974, 1980; Leibowitz, 1977; and Datcher-Loury, 1988). Negative values are set to zero, and childcare hours for individuals with no children are also set to zero. In addition, in the estimation and in the analysis, we do not use the hours with children measure directly; instead, we compute a discrete version of this measure with three levels of time spent with children (low, medium, and high) for fathers and mothers separately, which reduces the concerns about the representativeness of the measure. $\underline{2}$ 


\section{Table 1}

Summary Statistics

\begin{tabular}{|c|c|c|}
\hline & $N$ & Mean \\
\hline Female & 2,693 & $\begin{array}{c}0.476 \\
(0.499)\end{array}$ \\
\hline Black & 2,693 & $\begin{array}{c}0.266 \\
(0.441)\end{array}$ \\
\hline Child's education & 2,693 & $\begin{array}{l}13.33 \\
(2.007)\end{array}$ \\
\hline Number of siblings under age 3 & 2,307 & $\begin{array}{c}1.17 \\
(1.026)\end{array}$ \\
\hline Number of siblings between ages 3 and 6 & 2,307 & $\begin{array}{l}0.50 \\
(0.648)\end{array}$ \\
\hline Mother's education & 2,693 & $\begin{array}{l}13.10 \\
(2.072)\end{array}$ \\
\hline Father's education & 2,693 & $\begin{array}{l}13.25 \\
(2.408)\end{array}$ \\
\hline Mother's age when the child is age 1 & 2,227 & $\begin{array}{l}25.8 \\
(4.753)\end{array}$ \\
\hline Father's age when the child is age 1 & 2,227 & $\begin{array}{l}28.3 \\
(5.594)\end{array}$ \\
\hline Mother's time with child & 1,461 & $\begin{array}{l}5.49 \\
(2.590)\end{array}$ \\
\hline Father's time with child & 1,479 & $\begin{array}{c}2.75 \\
(2.748)\end{array}$ \\
\hline Mother's labor supply & 1,544 & $\begin{array}{l}4.77 \\
(3.905)\end{array}$ \\
\hline Father's labor supply & 1,586 & $\begin{array}{l}9.56 \\
(1.422)\end{array}$ \\
\hline Mother's labor income & 1,576 & $\begin{array}{l}5.22 \\
(6.113)\end{array}$ \\
\hline Father's labor income & 1,588 & $\begin{array}{c}20.55 \\
(11.991)\end{array}$ \\
\hline Year when the child is age 1 & 2,227 & $\begin{array}{c}1977 \\
(5.372)\end{array}$ \\
\hline
\end{tabular}

NOTE: Standard deviations are in parentheses. $N$ is the number of observations. All variables are measured annually. Education measures the years of completed education. There are fewer observations for annual housework hours than time spent with children because single individuals with no child are coded as missing housework hours and by definition their hours are set to zero for time spent with children. Labor income is measured yearly in 2005 dollars.

SOURCE: Data are from the "Family-Individual" file of the PSID and include individuals surveyed between 1968 and 1997. 
Gayle, Golan, Soytas

Table 2

OLS Estimation of the Production Function

\begin{tabular}{|c|c|c|c|c|c|c|}
\hline \multirow[b]{2}{*}{ Variable } & \multicolumn{3}{|c|}{ (1) } & \multicolumn{3}{|c|}{ (2) } \\
\hline & High school & Some college & College & High school & Some college & College \\
\hline Female & $\begin{array}{c}0.0047 \\
(0.0130)\end{array}$ & $\begin{array}{l}0.1257^{* * *} \\
(0.0194)\end{array}$ & $\begin{array}{l}0.0671^{* * *} \\
(0.0163)\end{array}$ & $\begin{array}{c}0.0027 \\
(0.0150)\end{array}$ & $\begin{array}{l}0.1250^{* * *} \\
(0.0239)\end{array}$ & $\begin{array}{l}0.0850^{* * *} \\
(0.0201)\end{array}$ \\
\hline Black & $\begin{array}{c}-0.0188 \\
(0.0152)\end{array}$ & $\begin{array}{c}-0.0233 \\
(0.0227)\end{array}$ & $\begin{array}{c}-0.0473^{* *} \\
(0.0191)\end{array}$ & $\begin{array}{c}0.0283 \\
(0.0176)\end{array}$ & $\begin{array}{c}0.0256 \\
(0.0281)\end{array}$ & $\begin{array}{c}-0.0190 \\
(0.0236)\end{array}$ \\
\hline High school father & $\begin{array}{l}0.0478^{* *} \\
(0.0216)\end{array}$ & $\begin{array}{l}0.0723^{* *} \\
(0.0322)\end{array}$ & $\begin{array}{c}0.0251 \\
(0.0271)\end{array}$ & $\begin{array}{l}0.0521^{* *} \\
(0.0256)\end{array}$ & $\begin{array}{c}0.0664 \\
(0.0408)\end{array}$ & $\begin{array}{c}0.0058 \\
(0.0343)\end{array}$ \\
\hline Some college father & $\begin{array}{l}0.0401^{* *} \\
(0.0175)\end{array}$ & $\begin{array}{l}0.1083^{* * *} \\
(0.0260)\end{array}$ & $\begin{array}{l}0.0623^{* * *} \\
(0.0219)\end{array}$ & $\begin{array}{c}0.0274 \\
(0.0203)\end{array}$ & $\begin{array}{l}0.0900^{* * *} \\
(0.0324)\end{array}$ & $\begin{array}{c}0.0423 \\
(0.0273)\end{array}$ \\
\hline College father & $\begin{array}{c}0.0016 \\
(0.0199)\end{array}$ & $\begin{array}{l}0.1172 * * * \\
(0.0296)\end{array}$ & $\begin{array}{l}0.1538^{* * *} \\
(0.0249)\end{array}$ & $\begin{array}{c}-0.0196 \\
(0.0229)\end{array}$ & $\begin{array}{c}0.0699 * \\
(0.0366)\end{array}$ & $\begin{array}{l}0.1321 * * * \\
(0.0308)\end{array}$ \\
\hline High school mother & $\begin{array}{l}0.1346^{* * *} \\
(0.0240)\end{array}$ & $\begin{array}{l}0.1781^{* * *} \\
(0.0357)\end{array}$ & $\begin{array}{c}0.0481 \\
(0.0299)\end{array}$ & $\begin{array}{l}0.0831^{* * *} \\
(0.0293)\end{array}$ & $\begin{array}{l}0.1631^{* * *} \\
(0.0468)\end{array}$ & $\begin{array}{c}0.0472 \\
(0.0393)\end{array}$ \\
\hline Some college mother & $\begin{array}{c}-0.0031 \\
(0.0169)\end{array}$ & $\begin{array}{l}0.0718^{* * *} \\
(0.0252)\end{array}$ & $\begin{array}{l}0.0691^{* * *} \\
(0.0211)\end{array}$ & $\begin{array}{c}-0.0022 \\
(0.0195)\end{array}$ & $\begin{array}{l}0.0877^{* * *} \\
(0.0311)\end{array}$ & $\begin{array}{l}0.0921 * * * \\
(0.0262)\end{array}$ \\
\hline College mother & $\begin{array}{c}0.0200 \\
(0.0206)\end{array}$ & $\begin{array}{l}0.0687^{* *} \\
(0.0307)\end{array}$ & $\begin{array}{l}0.0917^{* * *} \\
(0.0258)\end{array}$ & $\begin{array}{c}0.0004 \\
(0.0241)\end{array}$ & $\begin{array}{c}0.047 \\
(0.0384)\end{array}$ & $\begin{array}{c}0.0388 \\
(0.0323)\end{array}$ \\
\hline Mother's labor income & & & & $\begin{array}{c}-0.0014 \\
(0.0013)\end{array}$ & $\begin{array}{c}0.0001 \\
(0.0021)\end{array}$ & $\begin{array}{c}0.0013 \\
(0.0017)\end{array}$ \\
\hline Father's labor income & & & & $\begin{array}{l}0.0026^{* * *} \\
(0.0007)\end{array}$ & $\begin{array}{l}0.0033^{* * *} \\
(0.0012)\end{array}$ & $\begin{array}{l}0.0043^{* * *} \\
(0.0010)\end{array}$ \\
\hline Constant & $\begin{array}{l}0.7028^{* * *} \\
(0.0252)\end{array}$ & $\begin{array}{l}0.1234^{* * *} \\
(0.0375)\end{array}$ & $\begin{array}{c}0.0222 \\
(0.0315)\end{array}$ & $\begin{array}{l}0.7181^{* * *} \\
(0.0321)\end{array}$ & $\begin{array}{c}0.0917^{*} \\
(0.0512)\end{array}$ & $\begin{array}{c}-0.0506 \\
(0.0430)\end{array}$ \\
\hline Observations & 2,306 & 2,306 & 2,306 & 1,541 & 1,541 & 1,541 \\
\hline
\end{tabular}

We then describe the relationship between a child's educational outcome and parental education and income, controlling for race. In the relationship, we control for the race and gender of the child. Table 2 presents the results from the ordinary least-squares (OLS) estimation of a linear probability model. The outcome (dependent variable) is the educational attainment of the child. It is divided into four ordered categories according to the highest educational achievement of the child: high school dropout, high school graduate, some college education, and a four-year college degree or above. The category "high school dropout" is omitted from the table. Two specifications, labeled (1) and (2), estimate the linear probability system using children's educational outcomes as the only endogenous variables in the system.

Specification (1) presents the correlation between the educational outcomes of parents and children, controlling for the race and gender of the child. Consistent with findings in the literature, having a college-educated father or mother increases the probability of graduating from college and of having some college education. Having a father or a mother with some 
college education increases the probability of graduating from college (to a lesser degree than having college-educated parents) or having some college education. Having a mother or a father who is a high school graduate increases the probability of graduating from high school or having some college education but has a small and statistically insignificant effect on the probability of graduating from college (recall that the estimates are relative to having parents with less than a high school education).

Specification (2) adds the mother's and father's income in the first five years of their child's life to the variables already controlled for in specification (1). The income variables are an additional proxy for the parents' socioeconomic status. However, income can also directly affect educational attainment. We look at income only in the first five years because, if there are credit constraints, it may capture the inability to borrow and invest in children during those years. We find that a father's income has a positive, significant effect on a child's educational outcome. A mother's income, however, has no significant effect, which may not be surprising since many women take time off from the labor market to care for young children. Such time off might have a positive effect on a child's educational outcome that offsets the decline in income during the child's early years. The addition of the income variable changes the coefficients on the education variables. For example, there is no longer a significant effect of a mother's college education on her child's educational outcome, while there is still a significant effect of a father's college education on the outcome, although the effect is smaller than before. Clearly there is no causal interpretation because of endogeneity and selection issues.

\section{CAUSAL EFFECT OF PARENTAL EDUCATION, INCOME, AND TIME}

The above results on the impact of fathers' education on the education of their children are consistent with findings in the literature. However, there is disagreement in the literature about the importance of income and credit constraints on children's educational outcomes. We present below a simple framework for estimation of the production function of education that extends the regression models above. The specification of the production function facilitates a more transparent discussion of the empirical challenges of estimating the causal effect of parental education and skills, as well as investments and the assumptions made about them, on the educational outcomes of children.

\subsection{Framework}

To capture the impact of parents' characteristics and inputs on children's educational attainment, we specify an "education production function" that accounts for parental time and monetary investment in children as well as the parents' characteristics and skills. We denote a child's education by $e^{\prime}$ and the child's innate ability by $\eta^{\prime}$. The characteristics of children in the next generation $x^{\prime} \equiv\left(e^{\prime}, \eta^{\prime}\right)$ are affected by their parents' characteristics $x \equiv(e, \eta)$, early childhood monetary investment, early childhood time investments, and the presence and timing of siblings in early childhood. We further index the variables by gender; for instance, $e_{f}^{\prime}$ represents the educational outcome of a daughter in the next generation. This 
intergenerational production function written generically for a child of any gender is determined by the following set of equations:

$$
\begin{aligned}
& e_{f(m)}^{\prime}=\Gamma_{f(m)}\left(x, d^{(0)}, \ldots, d^{(5)}, w^{(0)}, \ldots, w^{(5)}, S_{-5}\right)+\omega_{f(m)}^{\prime} \\
& \eta_{f(m)}^{\prime}=\Gamma_{f(m) \eta}\left(e_{f(m)}^{\prime}\right)+\tilde{\eta}_{f(m)}^{\prime} \\
& \operatorname{Pr}\left(\tilde{\eta}^{\prime}=\tilde{\eta}_{i}\right)=F_{f(m)}\left(e_{f}, e_{m}, \eta_{f}, \eta_{m}\right) .
\end{aligned}
$$

In the empirical implementation, $\Gamma_{f(m)}$ and $\Gamma_{f(m) \eta}$ are both linear functions. The vector $d^{(j)}=\left(d_{f}^{(j)}, d_{m}^{(j)}\right)$ is the parental time investment at age $j$ of the child, $w^{(j)}$ is the household earnings at age $j$ of the child, $S_{-5}$ is the gender-adjusted number of young siblings present in the household during early childhood, and $\omega_{f(m)}^{\prime}$ is the gender-specific luck component that determines the educational outcome of the child. $\frac{3}{\text { A }}$ child's innate ability, $\eta_{f(m)}^{\prime}$, is determined once the education level is determined as the sum of systematic, $\Gamma_{f(m) \eta}\left(e^{\prime}\right)$, and random, $\tilde{\eta}_{f(m)}^{\prime}$, components. The random component, $\tilde{\eta}_{f(m)}^{\prime}$, is assumed to have finite support and to be independent of $\omega_{f(m)}^{\prime}$, with probability distribution function $F_{f(m)}\left(e_{f}, e_{m}, \eta_{f}, \eta_{m}\right)$. An important feature of this specification is that it divides the child's ability into a (i) a component determined by parental inputs through the effect of the educational outcome, (ii) innate ability, and (iii) a separable component that is directly transmitted through the parents' innate ability.

\subsection{Estimation}

Next, we estimate equations (1a) to (1c), which specify the intergenerational production function. We use an instrumental variable identification strategy with a linear probability model (IV-LPM). ${ }^{4}$ Although there are three other methods of estimating discrete choice

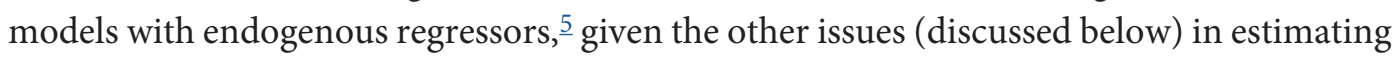
the intergenerational production functions, the IV-LPM is the most straightforward method for simultaneously dealing with all these issues.

There is a large literature on the estimation of the direct effect of parental traits and investment on children's income in adulthood (see Behrman, 1996; Behrman and Rosenzweig, 2002; and Lee, Roys, and Seshadri, 2014, among others). There are two well-known fundamental problems with estimating the causal intergenerational schooling effect of parents' education. The first is the standard-ability "bias" from the literature on the estimation of the returns to education. That is, more "able" parents may obtain more schooling: If schooling or earnings ability is genetically transmitted to their children, the intergenerational education correlation between children and parents may merely reflect that more-able parents who have more schooling have more-able children who obtain more schooling. The second problem is that the relationship among parental traits, investment, and children's educational outcomes is normally estimated for mothers and children only. Thus, even among mothers with the same abilities, those with higher education may have children with greater educational outcomes and labor market performance because of assortative mating (that is, more-educated women 


\section{Gayle, Golan, Soytas}

are more likely to marry more-educated men; thus, some of the estimated effects of mothers reflects the unobserved effects of their spouse).

The specification of the education production function in our model, equations (1a) to (1c), internalizes all these concerns, which are accounted for in the estimation as follows. First, we assume that observed ability in the labor market is a monotonic transformation of academic ability; therefore, by using the panel structure of our data, we are able to estimate fixed effects for both parents and children using data on earnings. ${ }^{6}$ These estimated fixed effects are then used in the estimation of the education production function to mitigate the ability bias. Second, we include a father's education and time with his child in the education production function while explicitly accounting for household interactions.

However, this approach leads to a third problem: the simultaneity of the inputs of both fathers and mothers and the endogeneity of which parent and type of parent spends time with their child (by "type of parent" we refer to the education and skills of the parent and their spouse). The output of the intergenerational education production function (i.e., the completed education level) is determined across generations, while the inputs, such as parental time investment, are determined over the life cycle of each generation. Therefore, we treat the inputs as predetermined and use instruments from within the system to estimate the production function. This leads to a system of equations that needs to be estimated simultaneously: equations (1a) to (1c), the education production function, as well as equations for the parental labor supply, income, and time spent with children.

To estimate our system, we need a number of exclusion restrictions. The first is the sex composition of siblings; it enters the education production function but not the labor-supply equations. This is similar to the siblings-sex ratio, first used by Angrist and Evans (1998) and is justified on the basis that the sex composition of the children does not have a direct effect on labor supply or the outcome of the child (again, the outcome of the child depends on the child's gender and number of siblings, but not the siblings' sex composition). However, sex composition has an indirect effect on parental time investment in children because (i) parents potentially spend different amounts of time with boys and girls and (ii) it may affect fertility decisions (parents might have preferences, for example, for a balanced sex composition of their children). The second set of instruments-the difference in the age-earnings profile by education-is used to provide quasi-experimental variation in income, labor supply, and subsequent fertility decisions. ${ }^{-}$See Gayle, Golan, and Soytas (2014) for more details and a theoretical intergenerational model that justifies these exclusion restrictions.

\subsection{Results}

Table 3 presents results of a three-stage least-squares estimation of the system of individual educational outcomes for the educational outcomes equations only. $\underline{-}$ The entire system includes equations for educational outcomes of children, parental time investments, parental incomes, and the parental labor supply. Therefore, in total, a system with nine endogenous variables is estimated. Parental time investment is the sum of the parental time investment over the first five years of the child's life for each parent. The total time investment is a variable that ranges from 0 to 10 , since low parental investment is coded as 0 and high parental invest- 


\section{Table 3}

\section{Three-Stage Least-Squares Estimation of the Production Function}

\begin{tabular}{|c|c|c|c|}
\hline Variable & High school & Some college & College \\
\hline Female & $\begin{array}{c}-0.0036 \\
(0.0166)\end{array}$ & $\begin{array}{l}0.1363^{* * *} \\
(0.0275)\end{array}$ & $\begin{array}{l}0.0863^{* * *} \\
(0.0222)\end{array}$ \\
\hline Black & $\begin{array}{c}0.0070 \\
(0.0388)\end{array}$ & $\begin{array}{c}0.0658 \\
(0.0626)\end{array}$ & $\begin{array}{c}0.0268 \\
(0.0506)\end{array}$ \\
\hline High school father & $\begin{array}{l}0.0731^{* *} \\
(0.0324)\end{array}$ & $\begin{array}{c}0.0045 \\
(0.0525)\end{array}$ & $\begin{array}{c}-0.0055 \\
(0.0426)\end{array}$ \\
\hline Some college father & $\begin{array}{l}0.0548^{* *} \\
(0.0235)\end{array}$ & $\begin{array}{l}0.1301^{* * *} \\
(0.0381)\end{array}$ & $\begin{array}{c}0.0547^{*} \\
(0.0309)\end{array}$ \\
\hline College father & $\begin{array}{c}-0.0416 \\
(0.0319)\end{array}$ & $\begin{array}{c}0.0083 \\
(0.0513)\end{array}$ & $\begin{array}{l}0.1169^{* * *} \\
(0.0419)\end{array}$ \\
\hline High school mother & $\begin{array}{l}0.0911^{* *} \\
(0.0403)\end{array}$ & $\begin{array}{c}0.0949 \\
(0.0646)\end{array}$ & $\begin{array}{c}-0.0116 \\
(0.0523)\end{array}$ \\
\hline Some college mother & $\begin{array}{c}0.0251 \\
(0.0306)\end{array}$ & $\begin{array}{c}-0.0257 \\
(0.0491)\end{array}$ & $\begin{array}{c}0.0213 \\
(0.0398)\end{array}$ \\
\hline College mother & $\begin{array}{l}0.0872^{* *} \\
(0.0364)\end{array}$ & $\begin{array}{l}0.1271^{* *} \\
(0.0575)\end{array}$ & $\begin{array}{c}0.0432 \\
(0.0472)\end{array}$ \\
\hline Mother's labor income & $\begin{array}{l}-0.0277^{* * *} \\
(0.0087)\end{array}$ & $\begin{array}{c}-0.0170 \\
(0.0137)\end{array}$ & $\begin{array}{c}0.0035 \\
(0.0114)\end{array}$ \\
\hline Father's labor income & $\begin{array}{c}0.0011 \\
(0.0025)\end{array}$ & $\begin{array}{c}0.0010 \\
(0.0039)\end{array}$ & $\begin{array}{c}0.0024 \\
(0.0033)\end{array}$ \\
\hline \multirow[t]{2}{*}{ Number of siblings under age 3} & -0.0063 & $-0.1018^{* * *}$ & $-0.0376^{*}$ \\
\hline & $(0.0166)$ & $(0.0270)$ & $(0.0218)$ \\
\hline Number of siblings between ages 3 and 6 & $\begin{array}{c}-0.0292 \\
(0.0186)\end{array}$ & $\begin{array}{l}-0.0456 \\
(0.0302)\end{array}$ & $\begin{array}{c}-0.0117 \\
(0.0246)\end{array}$ \\
\hline Mother's time with child & $\begin{array}{c}-0.0331 \\
(0.0207)\end{array}$ & $\begin{array}{l}0.0668^{* *} \\
(0.0334)\end{array}$ & $\begin{array}{l}0.0595^{* *} \\
(0.0270)\end{array}$ \\
\hline Father's time with child & $\begin{array}{c}0.0283 \\
(0.0186)\end{array}$ & $\begin{array}{l}0.1019^{* * * *} \\
(0.0293)\end{array}$ & $\begin{array}{c}0.0328 \\
(0.0246)\end{array}$ \\
\hline Constant & $\begin{array}{l}0.9533^{* * *} \\
(0.1087)\end{array}$ & $\begin{array}{c}-0.1619 \\
(0.1738)\end{array}$ & $\begin{array}{c}-0.3259 * * \\
(0.1414)\end{array}$ \\
\hline Observations & 1,332 & 1,332 & 1,332 \\
\hline
\end{tabular}

ment is coded as 2. Income variables are constructed as the sum of the annual income of each parent over the first five years of the child's life and measured in 2005 dollars. The labor supply is coded for each parent annually as 0,1 , or 2 corresponding to no work, part-time work, and full-time work. Therefore, the total labor supply is a variable that sums the labor supply over the first five years of the child's life and ranges from 0 to 10. 


\section{Gayle, Golan, Soytas}

The education and the race of the parents remain as the exogenous variables in the system estimation, as does the sex of the child. However, sex composition of the siblings and the ages of the parents serve as instruments. Age is measured as the age of the father (mother) when the child was five years old. Two variables are constructed for measuring the effect of sex composition. The variable "Number of siblings under age 3 " is the number of siblings less than age 3 when the child was less than 6 years old. Similarly, the variable "Number of siblings between ages 3 and 6 " is the number of siblings between the ages of 3 and 6 when the child was less than 6 years old. In the income and labor supply equations only, we use the age of each parent, the age of each parent squared, the age of each parent cubed, and the age of each parent interacted with his or her education. Therefore, we use the exclusion restriction that this set of instruments does not affect the educational outcome equations. Secondly, we use the variables "Number of siblings under age 3" and "Number of siblings between ages 3 and 6" only in the parental time and educational outcome equations, imposing the exclusion restriction that sex composition does not affect the labor supply and income outcomes.

The estimation results show that controlling for all inputs, a child whose mother has a college education has a higher probability of obtaining at least some college education and a significantly lower probability of not graduating from high school relative to a child with a less-educated mother; while the probability of the child graduating from college is also larger, it is not statistically significant. If a child's father, however, has some college or a college education, the child has a higher probability of graduating from college.

Table 3 also shows that while a mother's time investment significantly increases the probability of a child graduating from college or having some college education, a father's time investment significantly increases the probability of the child graduating from high school or having some college education. These estimates suggest that a mother's time investment increases the probability of a high educational outcome, while a father's time investment truncates a low educational outcome. However, the time investment of both parents is productive in terms of a child's educational outcome.

It is important to note that the hours mothers and fathers spend with their children are at different margins, with mothers spending significantly more time with the children than fathers. Thus, the magnitudes of the discrete levels of time investment of mothers and fathers are not directly comparable since what constitutes low and high investment differs across genders.

Figure 1 highlights the relative magnitudes. It shows that fathers' time investment does have a significant impact on the educational outcomes of children. For example, in a household where both parents are high school dropouts, a daughter would have a 3 percent chance of graduating from college if the mother has the sample average time investment and the father has a low time investment for the first five years of the child's life. However, the chance of graduating from college increases to 16 percent if the father increases his time investment to the sample average while the mother's time investment remains at the sample average. A similar pattern holds for all other household types.

Figure 2 highlights the relative importance of parental time investments versus the automatic transmission of education level from parents to children. It highlights the role of both 


\section{Figure 1}

\section{Three-Stage Least-Squares Estimates of the Relative Importance of Fathers' and Mothers' Time Investment on Children's Educational Outcomes}

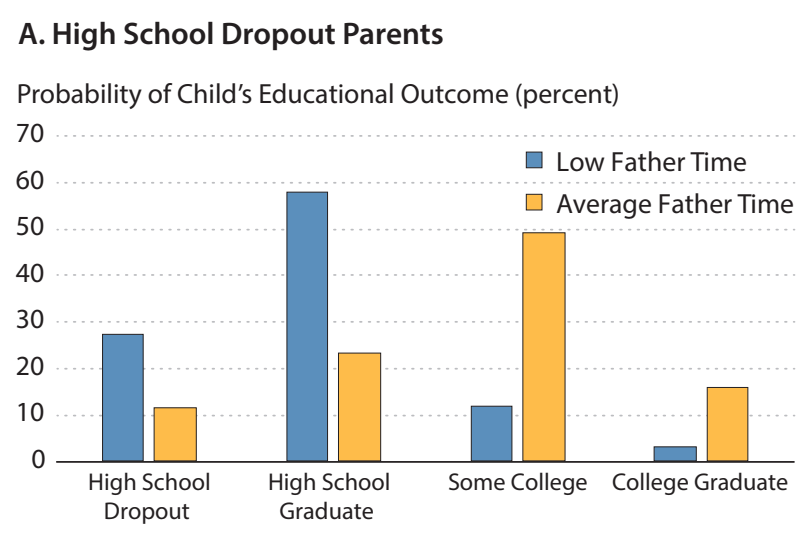

Education Level

\section{Some College Parents}

Probability of Child's Educational Outcome (percent)

70

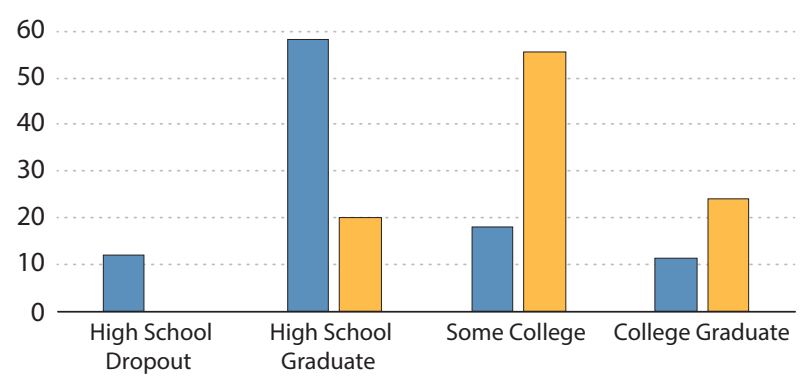

Education Level

\section{B. High School Graduate Parents}

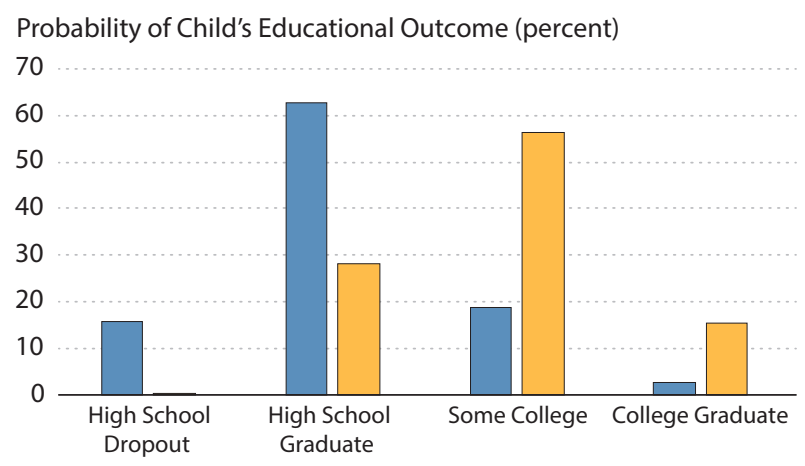

Education Level

\section{College Graduate Parents}

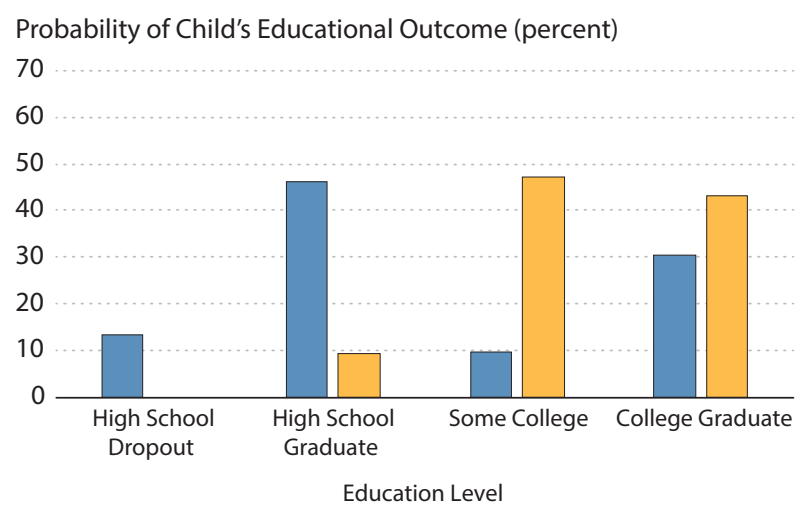

"nature" (education status is automatically transferred from parents to children) and "nurture" (more parental time with children increases the probability of the children having higher educational outcomes). The relative importance of nature versus nurture in accounting for the persistence of earnings across generations is a quantification question that needs to be answered with an optimizing behavioral framework, and parents may take actions that either enhance or diminish the relative effects of nature versus nurture.

\section{DISCUSSION AND CONCLUSIONS}

In this article, we identify the causal effects of parental traits, time investment, and income in early childhood on children's educational outcomes. We find that after accounting for parental education, skills, and income, both a father's and mother's time investment in the 


\section{Figure 2}

\section{Three-Stage Least-Squares Estimates of Parental Time Investment Versus the Causal Impact of Parental Education on Children's Educational Outcomes}

\section{A. High School Dropout Parents}

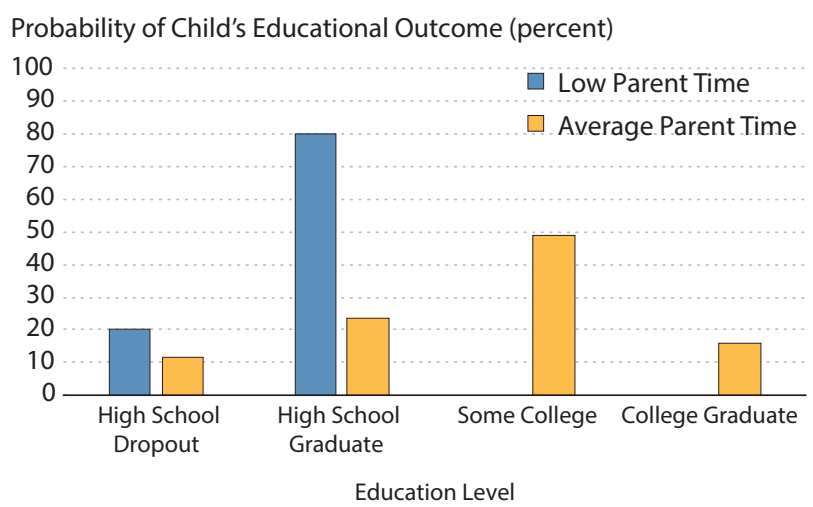

\section{Some College Parents}

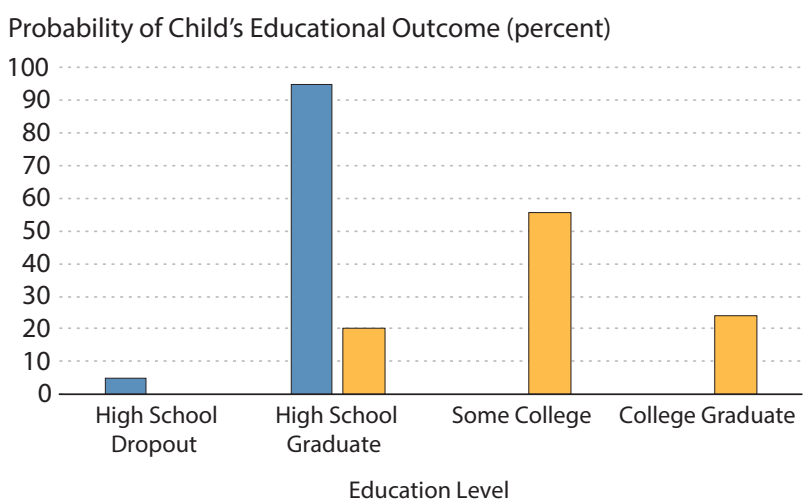

\section{B. High School Graduate Parents}

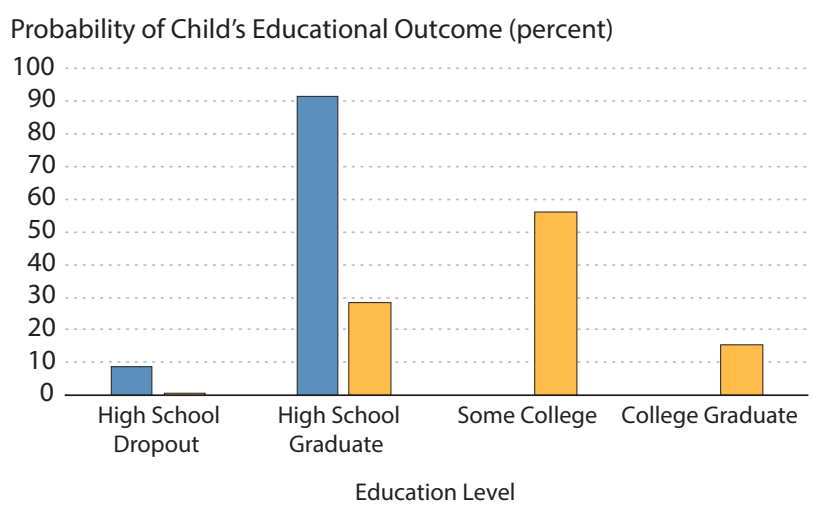

\section{College Graduate Parents}

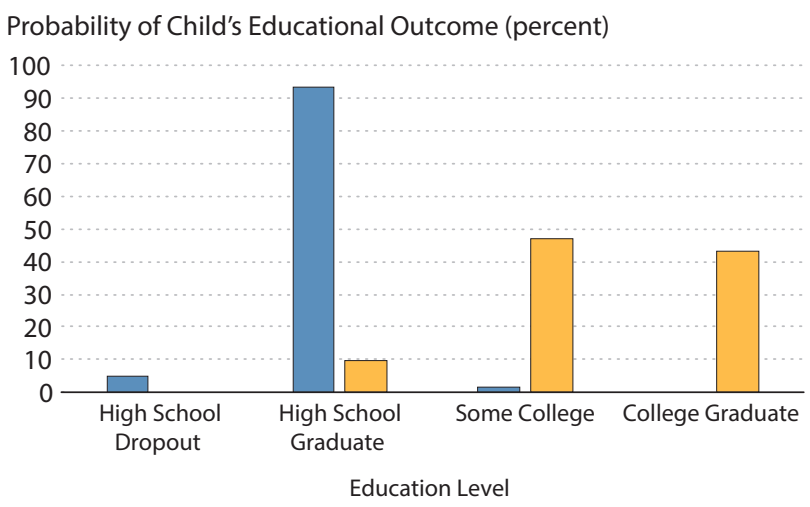

first five years of a child's life have a large effect on the child's completed education. We find that when a father increases his time investment from low to the average while the mother is at the average, the probability that the child graduates from college increases by 13 percent. When a mother increases her time investment from low to average while the father is at the average, the probability of a child graduating from college increases by 16 percent.

Controlling for all other inputs and parental characteristics, we find that girls have a higher probability of graduating from college. In addition, we do not find evidence for the importance of income in early childhood on children's educational attainment. There is debate in the literature on the effect of credit constraints on children's educational attainment (see Heckman and Mosso, 2014, for a comprehensive review). However, we look at income only in the first five years of a child's life, and it is possible that credit constraints and monetary investment play a more important role later on in a child's development and quality of school- 
ing. Furthermore, credit constraints can have an effect on children's educational outcomes to the extent that credit constraints affect the time parents spend with young children. These issues are important and will be analyzed in future work.

While estimating the causal effects on education in early childhood is important, it is not sufficient for policy assessment. Time investment and monetary inputs, as well as fertility decisions, all potentially affect children's educational outcomes. However, these are all parental decisions that may be affected by different policies. Currently, there is little known on the underlying mechanisms affecting parental choices and input.

A handful of recent papers have analyzed the underlying mechanisms affecting parental choices (see Gayle, Golan, and Soytas, 2014, 2015, and Lee and Seshadri, 2015). Specifically, Lee and Seshadri (2015) and Gayle, Golan, and Soytas (2015) account for the role of investment decisions in the underlying intergenerational correlation in earnings. As we concluded, there is a causal effect of fathers' education and of fathers' and mothers' time during early childhood on children's educational outcomes. However, due to assortative mating, which has increased over the past decades, and because parental time with children depends on how households allocate time among labor market activities, leisure, and household work, understanding the role of the marriage market and households is central to understanding intergenerational mobility patterns.

Gayle, Golan, and Soytas $(2014,2015)$ explicitly analyze the impact of markets on fertility decisions, household time allocation, and the educational outcomes of children. They find that parental time with children is greatly impacted by marriage markets, and the labor market structure (meaning the nonlinear nature of the return to the labor market and full-time versus part-time work as well as the racial and gender pay gaps). Therefore, the marriage market and the labor market structure have a significant impact on intergenerational mobility, long-term labor market outcomes, and the welfare of children. These findings thus support the large research emphasizing the importance of policies aimed at investment in early childhood. We suggest that it is important to consider the impact of policies on parental time investment in children. 


\section{Gayle, Golan, Soytas}

\section{NOTES}

1 Starting in 1997, the Child Development Supplement of the PSID provides more extensive family data on children, including parental time on childcare.

$\underline{2}$ For robustness, we benchmarked our constructed parental time variable from the PSID with the data from the American Time Use Survey. See Gayle, Golan, and Soytas (2014).

$\underline{3}$ Indexes $(f, m)$ are used similarly to represent the mother's and father's time investments.

4 One reason to use a linear specification is that the nonlinearity in the intergenerational production function itself can generate persistence in earnings across generations. However, we wanted to focus on the economic mechanism that generates persistence of earnings across generations.

5 The three are the maximum likelihood, control variable, and special regressor approaches. See Lewbel, Dong, and Yang (2012) for a comparison of the different approaches.

$\underline{6}$ For complete estimation details and results of the fixed effects in the labor markets, see Gayle, Golan, and Soytas (2014).

1 More specifically, the ages of the parents when the child is five years old has an effect on the labor supply because age and education have a deterministic effect on earnings. However, age does not affect directly time investment in children.

8 For the estimates of the entire system, see Gayle, Golan, and Soytas (2014).

\section{REFERENCES}

Angrist, Joshua D. and Evans, William N. “Children and Their Parents' Labor Supply: Evidence from Exogenous Variation in Family Size." American Economic Review, June 1998, 88(3), pp. 450-77; http://www.jstor.org/stable/116844.

Behrman, Jere R. "From Parent to Child," in Jon R. Neill, ed., Poverty and Inequality: The Political Economy of Redistribution. Kalamazoo, MI: W.E. Upjohn Institute for Employment Research, 1996, pp. 105-26; https://doi.org/10.17848/9780585314402.ch6.

Behrman, Jere R. and Rosenzweig, Mark R. "Does Increasing Women's Schooling Raise the Schooling of the Next Generation?" American Economic Review, March 2002, 92(1), pp. 323-34; https://doi.org/10.1257/000282802760015757.

Black, Sandra E. and Devereux, Paul J. "Recent Developments in Intergenerational Mobility," in David Card and Orley Ashenfelter, eds., Handbook of Labor Economics. Volume 4, Part B. Amsterdam, Netherlands: Elsevier, 2011, pp. 1487-541; https://doi.org/10.1016/S0169-7218(11)02414-2.

Datcher-Loury, Linda. "Effects of Mother's Home Time on Children's Schooling." Review of Economics and Statistics, August 1988, 70(3), pp. 367-73; https://doi.org/10.2307/1926773.

Del Boca, Daniela; Flinn, Christopher and Wiswall, Matthew. "Household Choices and Child Development." Review of Economic Studies, January 2014, 81(1), pp. 137-85; https://doi.org/10.1093/restud/rdt026.

Gayle, George-Levi; Golan, Limor and Soytas, Mehmet A. "What Accounts for the Racial Gap in Time Allocation and Intergenerational Transmission of Human Capital?" Unpublished manuscript, Washington University in St. Louis, Department of Economics, October 2014.

Gayle, George-Levi; Golan, Limor and Soytas, Mehmet A. "What Is the Source of the Intergenerational Correlation in Earnings?" Working Paper 2015-019A, Federal Reserve Bank of St. Louis, August 2015; https://research.stlouisfed.org/wp/2015/2015-019.pdf.

Heckman, James J. and Mosso, Stefano. "The Economics of Human Development and Social Mobility." Annual Review of Economics, August 2014, 6, pp. 689-33; https://doi.org/10.1146/annurev-economics-080213-040753.

Hill, C. Russell and Stafford, Frank P. "Allocation of Time to Preschool Children and Educational Opportunity." Journal of Human Resources, 1974, 9(3), pp. 323-41; http://doi.org/10.2307/144690. 
Hill, C. Russell and Stafford, Frank P. "Parental Care of Children: Time Diary Estimates of Quantity, Predictability, and Variety." Journal of Human Resources, 1980, 15(2), pp. 219-39; http://doi.org/10.2307/145332.

Lee, Sang Yoon; Roys, Nicholas and Seshadri, Ananth. "The Causal Effect of Parental Human Capital on Children's Human Capital." Unpublished manuscript, University of Wisconsin-Madison, Department of Economics, December 2014.

Lee, Sang Yoon and Seshadri, Ananth. "On the Intergenerational Transmission of Economic Status." Unpublished manuscript, University of Wisconsin-Madison, Department of Economics, January 2015.

Leibowitz, Arleen. "Parental Inputs and Children's Achievement." Journal of Human Resources, 1977, 12(2), pp. 242-51; http://doi.org/10.2307/145387.

Lewbel, Arthur; Dong, Yingying and Yang, Thomas T. "Comparing Features of Convenient Estimators for Binary Choice Models with Endogenous Regressors." Canadian Journal of Economics, August 2012, 45(3), pp. 809-29; http://doi.org/10.1111/j.1540-5982.2012.01733.x. 
